\title{
Numerical Analysis for layout methods on h-shaped double row piles
}

\author{
ZHAN Zhiqi ${ }^{1,3}$, XU Guangli ${ }^{1,2^{*}}$, MAHLER András ${ }^{3}$ and LUO Xin ${ }^{1}$ \\ ${ }^{1}$ Institute of Geological Survey, China University of Geosciences (Wuhan), Wuhan, Hubei 430074, China. \\ ${ }^{2}$ Faculty of Engineering, China University of Geosciences (Wuhan), Wuhan, Hubei 430074, China. \\ ${ }^{3}$ Faculty of Civil Engineering, Budapest University of Technology and Economics, Budapest 1111, Hungary.
}

\begin{abstract}
In this thesis, the numerical models of multi-stages excavation foundation pit with h-shaped double row piles as the retaining structure were built by finite element software PLAXIS 3D with HS small model as the constitutive equation for soil layers, then the numerical models for two different pile layout methods, parallel layout and staggered layout, were calculated, calculation results were compared. The numerical calculation result shows that back row piles stand most load, so they need to be strengthened during the design and construction process; the bending moment of back row piles at the position connecting with beam is the largest, which need to be strengthened; the h-shaped double row piles with staggered layout method is better than the parallel way, which could be used to improve the safety of engineering, as well as achieving economic rationality.
\end{abstract}

\section{Introduction}

Nowadays, the construction of urban rail transit, infrastructure, comprehensive pipe gallery, underground space complex, residential and commercial complex is in full swing. When the ground space cannot meet human needs, it is inevitable to explore deeper and wider underground space, and foundation pit engineering play an important role in underground space exploitation.

The double-row piles with connecting beam is a new type of engineering measure that double-row piles connected by the beam, as a new type of retaining structure, compared with general single row piles it will be a more effective retaining engineering measure ${ }^{[1]}$. At present, the application of double row piles in foundation pit and landslide treatment has been studied deeply. The main research methods include numerical simulation, laboratory/ in-situ test and theoretical analysis. Ginzburg et al. ${ }^{[2]}$ studied the mixed clay soil landslide controlled by multiple rows of anti slide piles, and got the distribution law of landslide thrust on the anti slide piles. Xiong et al. ${ }^{[3]}$ studied the landslide thrust distribution law for multiple rows of piles with different layout ways by laboratory test; Liu et al. ${ }^{[4]}$ obtained through the nonlinear finite element method that when the cantilever double row anti slide pile is arranged in staggered way, the soil arching effect between piles is more obvious than that in parallel layout; Wang et al. ${ }^{[5]}$ studied the influence of the connecting beam stiffness and row spacing on the double row pile support structure by finite element software; Li et al. ${ }^{[6]}$ used FLAC 3D to study the mechanical characteristics of various types micro pile systems under different layouts and pile spacing.
Above all, there is not enough research about special type retaining piles like $\mathrm{h}$-shaped double row piles. The aim of this thesis work is to analyse the interaction mechanism between soil and h-shaped double row piles, find the best layout way for h-shaped double row piles. We use finite element software PLAXIS 3D to build a multi-stage deep excavation engineering model, find the best layout way for h-shaped double row piles, and give suggestion for engineering design.

\section{Numerical model}

\subsection{The size of model}

It is a multi-stage excavation model. For 3D model, the overall size of model is $100 \mathrm{~m}$ in $\mathrm{X}$ direction, $50 \mathrm{~m}$ in $\mathrm{Z}$ direction and $4 \mathrm{~m}$ in $\mathrm{Y}$ direction. The total excavation depth is $15 \mathrm{~m}$, with 3 steps excavation.

The multi-stage excavation model consists of three parts: soil layers, building and h-shaped double row piles. There is a $10 \mathrm{~m}$ high building with $2 \mathrm{~m}$ underground locating $5 \mathrm{~m}$ behind the excavation slope. There is a $3 \mathrm{~m}$ high excavation slope for excavation 1, the slope angle is $45^{\circ}$. For h-shaped double row piles, we define the piles near the building are back row piles, and the piles far away from building are front row piles, there is the connecting beam between these 2 row piles.

For the back row pile, the length is $22 \mathrm{~m}$, and for the front row pile is $17 \mathrm{~m}$, the spacing between same row piles is $2 \mathrm{~m}$. The underground water level is in the bottom of model.

Corresponding author: xu1963@cug.edu.cn 
Excavation 1 depth is $3 \mathrm{~m}$, excavation 2 is $5 \mathrm{~m}$ and excavation 3 is $7 \mathrm{~m}$. For the detail of model we can see in Figure 1.

And for practical engineering, there are many kinds of layout way for front and back piles, lead to different layout for connecting beam. We choose 2 of them for our research.

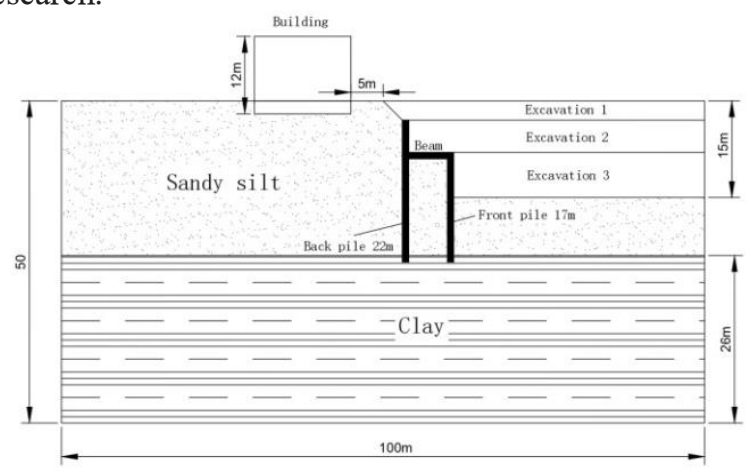

Fig. 1. The profile of 3D model

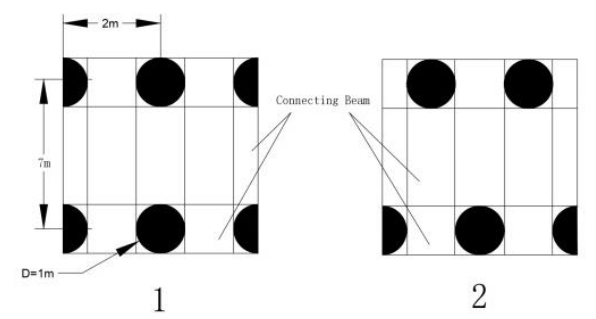

Fig. 2. The cross section of 3D model

We define parallel layout as way 1 and staggered layout as way 2 (Fig.2).

In this paper, I use fine element distribution for 3D model.

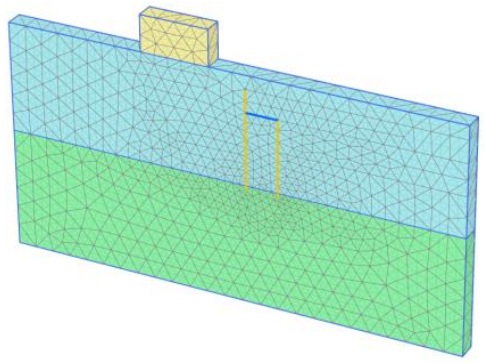

Fig. 3. 3D model

\subsection{The parameter of material}

For piles and beams, we choose structure unit embedded beam to simulate them (Elastic material).

Table 1. Structure unit Parameters

\begin{tabular}{|c|c|c|c|c|}
\hline & $\mathrm{E}$ & $\gamma$ & $\mathrm{D}$ & $\mathrm{L}_{\text {spacing }}$ \\
\hline \multirow{2}{*}{$\begin{array}{c}\text { Beam } \\
\text { and piles }\end{array}$} & $\mathrm{kN} / \mathrm{m}^{2}$ & $\mathrm{kN} / \mathrm{m}^{3}$ & $\mathrm{~m}$ & $\mathrm{~m}$ \\
\cline { 2 - 5 } & $4 \times 10^{7}$ & 24 & 1 & 2 \\
\hline
\end{tabular}

There are 2 soil layers, the first soil layer is sandy silt, the thickness of sandy silt is $24 \mathrm{~m}$; the second soil layer is clay, the thickness of clay is $26 \mathrm{~m}$. For the soil material, we choose the practical soil material parameter in Henan, and the constitutive model of soil material for calculation is HS small model, we could see the parameters of soil in Table 2.

Table 2. Soil layers parameters

\begin{tabular}{|c|c|c|c|}
\hline \multicolumn{2}{|c|}{ Parameter $/$ Soil } & Sandy silt & Clay \\
\hline$\gamma_{\text {unsat }}$ & $\mathrm{kN} / \mathrm{m}^{3}$ & 20 & 20 \\
\hline$\gamma_{\text {sat }}$ & $\mathrm{kN} / \mathrm{m}^{3}$ & 21 & 21 \\
\hline $\mathrm{E}_{50}{ }^{\text {ref }}$ & $\mathrm{kN} / \mathrm{m}^{2}$ & 25.000 & 27.200 \\
\hline${\text { E } \text { eed }^{\text {ref }}}^{\text {ref }}$ & $\mathrm{kN} / \mathrm{m}^{2}$ & 25.000 & 27.300 \\
\hline $\mathrm{E}_{\text {ur }}{ }^{\text {r }}$ & $\mathrm{kN} / \mathrm{m}^{2}$ & 75.000 & 81.000 \\
\hline $\mathrm{m}$ & - & 0,80 & 0,55 \\
\hline $\mathrm{c}_{\text {ref }}$ & $\mathrm{kN} / \mathrm{m}^{2}$ & 31 & 25 \\
\hline$\varphi^{\prime}$ & $\circ$ & 26 & 31 \\
\hline$\psi$ & $\circ$ & 0 & 0 \\
\hline$\gamma_{0,7}$ & - & 0,00025 & 0,001 \\
\hline $\mathrm{G}_{0}{ }^{\text {ref }}$ & $\mathrm{kN} / \mathrm{m}^{2}$ & 170.000 & 180.000 \\
\hline $\mathrm{OCR}$ & - & 1,0 & 1,0 \\
\hline
\end{tabular}

\section{Numerical analysis}

\subsection{Safety factor and building displacement}

First, we should check the safety factor.

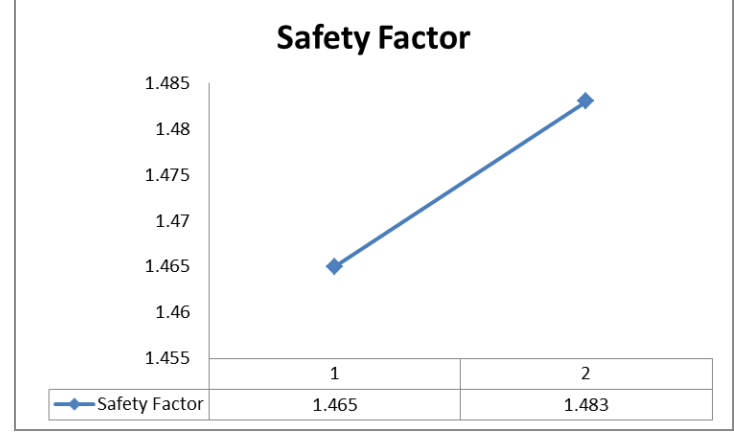

Fig. 4. Safety factor

We could compare the safety factor change with different layout way in Figure 4. These 2 layout ways will both meet the requirement of safety, and layout way 2 will be better, safety factor is 1.483 .

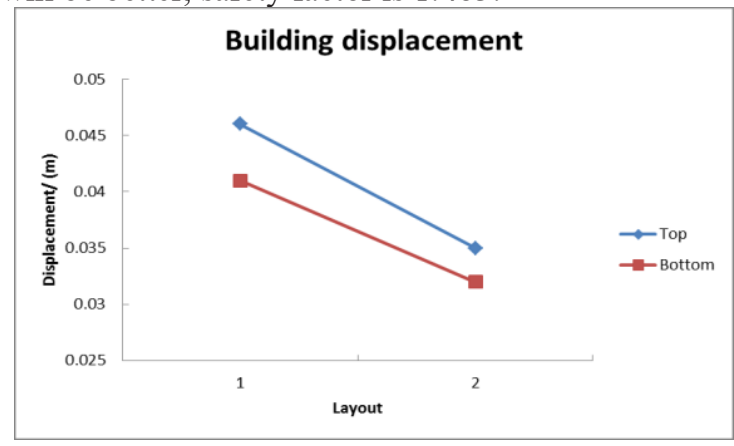

Fig. 5. Building displacement with different layout ways

From Figure 5 we can get that the building top displacement is larger than bottom. And layout 2 will 
lead to less building displacement both in top and bottom, so layout way 2 is the better 1 for this part.

\subsection{Pile displacement and bending moment}

Next we should compare the $\mathrm{X}$ direction displacement of back and front piles.

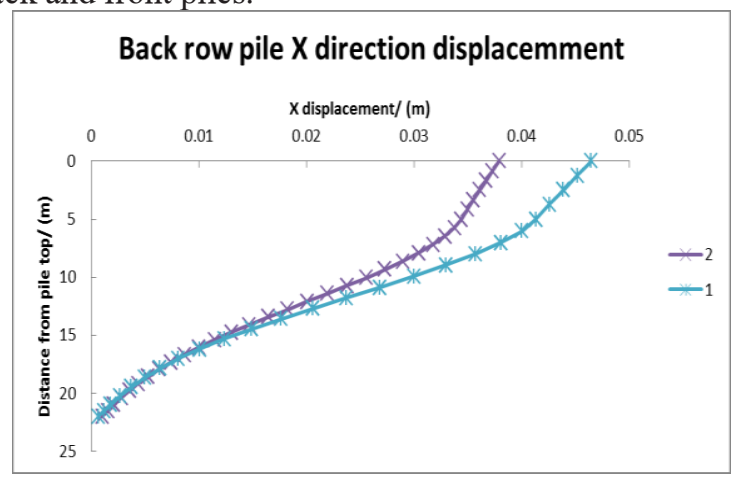

Fig. 6. Back row pile displacement with different layout ways

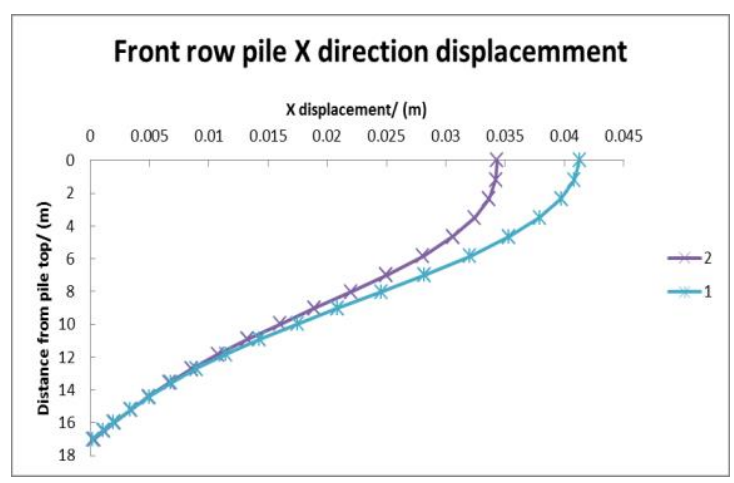

Fig. 7. Front row pile displacement with different layout ways

From Figure 6 and Figure 7 we can get that the back pile displacement is larger than front pile, the largest displacement located in the pile top, there is few displacement near the pile bottom. And the pile displacement of layout way 2 will be less than layout way 1.

From Figure 8, we can get that the bending moment of the back row pile is about 0 when the depth is $0-5 \mathrm{~m}$, and there is a sudden change at $5 \mathrm{~m}$ (the depth of the connecting beam), it is the maximum bending moment of the pile body, so it is necessary to strengthen to meet the safety requirements.

With the increase of depth, the bending moment first decreases and then increases to opposite direction, finally decrease to 0 . There is a reverse bending point near the middle point of the pile. The upper bending moment of the reverse bending point is in the negative direction, while the lower bending moment is in the opposite direction.

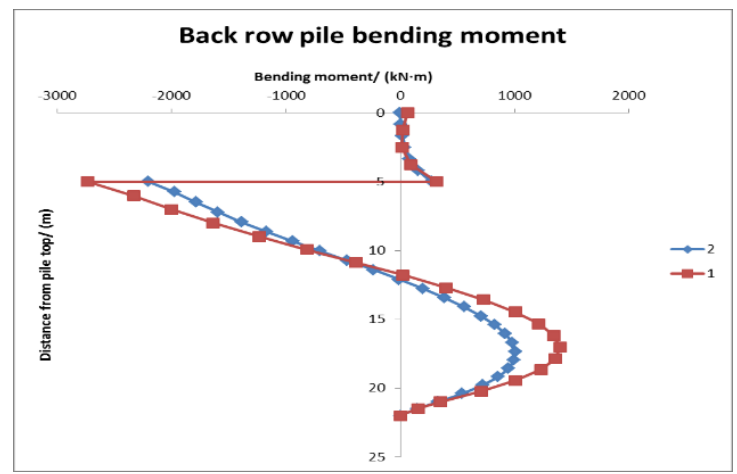

Fig. 8. Back row pile bending moment with different layout ways

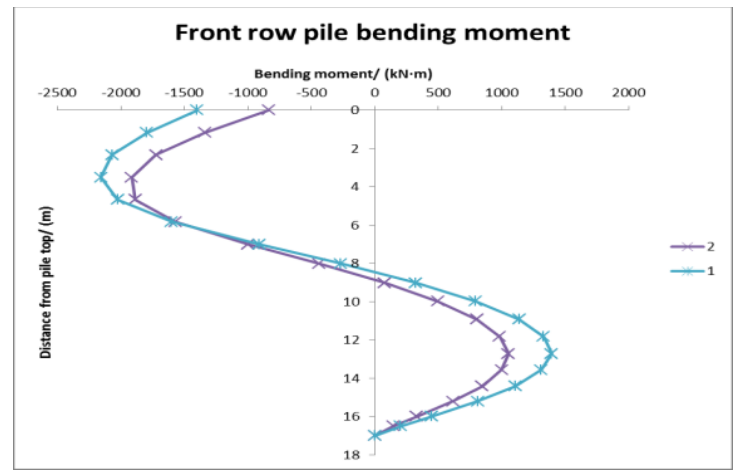

Fig. 9. Front row pile bending moment with different layout ways

From Figure 9, we can see that, unlike the back pile, the bending moment of the front pile top is not 0 . With the increase of depth, the bending moment first decreases and then increases to opposite direction, finally decrease to 0 . There is a reverse bending point near the middle of the pile. The upper bending moment of the reverse bending point is in the negative direction, the lower direction is opposite, and the maximum bending moment is at the buried depth of about $4 \mathrm{~m}$.

Back piles bending moment is larger than front piles. No matter for the back row piles or the front row piles, the bending moment of the double row piles arranged in parallel is greater than that of the staggered way. The maximum bending moment of the back row piles arranged in parallel is about 1.2 times of that of the staggered way, and the maximum bending moment of the front row piles is about 1.1 times of that of the staggered type. For the reverse bending point, the double row piles with staggered layout are closer to the center of the pile body, the internal force distribution is more balanced, which is better than the parallel layout.

\section{Conclusion}

We build the multi-stages excavation foundation pit model by Plaxis 3D, and then compare calculation results for two different pile layout methods, parallel layout and staggered layout. We can get that:

(1) For the double row piles, these two rows of piles cannot play the same effect, and the back row piles stand most of the load. 
(2) For h-shaped double row piles, connecting beam can coordinate the distribution of pile internal force. However, the joint between the connecting beam and pile (especially the back pile) will cause a sudden stress change, which is the position needs to be strengthened to meet the safety requirements.

(3) The layout methods of double row piles have great influence on the safety factor, buildings around the foundation pit, the displacement and internal force of the piles. The staggered layout is better than the parallel layout, which could meet safety requirement, as well as economics rationality.

\section{References}

1. The Second Survey and Design Institute of the Ministry of Railways. Design and calculation of anti-slide piles. M. China Railway Publishing House, (1983).

2. Ginzburg L K, Koval V E, Lapkin V B, et al. Force distribution among slope-protection structure pile rows. J. Soil Mechanics and Foundation Engineering, 27(2):52-58 (1990).

3. Xiong Zhiwen, Ma Hui, Zhu Haidong. Stress Distribution of Fully Buried Double-row Anti-slide Piles. J. Subgrade Engineering (2002(3)).

4. Liu J L, Wang J L, Yuan F. Influence of layout style on soil arching effect of double-row anti-slide piles. J. Journal of Graduate School of the Chinese Academy of Sciences, 364-369, 27(3), (2010).

5. Wang Zhongkai, Ma Qiang. Study on Working Performance Test and Simulation of Double-row Pile and Anchored Composite Supporting Structure in Soft Soil Foundation Pit. J. Safety and Environmental Engineering, 170-174, 23(6) (2016).

6. Li Xin, Li Changlong, Bai Mingzhou, et al. Effect of pile spacing and pile layout on the stress of micropile supporting system. J. Journal of Beijing Jiaotong University, (2017(4)). 